\title{
APPENDIX: NINA BERBEROVA'S LETTERS TO MAGNUS LJUNGGREN
}

4 января 1982

Многоуважаемый профессор Магнус Юнггрен,

очень была тронута Вашим вниманием. Ваше очень для меня ценное письмо про Иду я прочитала много раз. ${ }^{651}$ Лет 12 тому назад одна моя студентка нашла ее, пошла к ней. С тех пор к ней заходят мои американские друзья, навещают ее, и очень ее ценят. О том как именно умер Фроман я знала, но для того чтобы закамуфлировать всю историю, мне пришлось выдумать ему другой конец. ${ }^{652}$ Я знала уже в то время, как мучили (годами! десятилетиями!) Иду, и ужасно боялась за нее. «Курсив мой« по-русски выйдет осенью-зимой вторым изданием, и будет ей послан. Ошибки будут исправлены, смерти вписаны в Указатель, и т.д. Видели ли Вы мою недавно вышедшую книгу «Железная Женщина«? $?^{653}$ В библиотеке Стокгольмского ун-та она должна быть. Прочтите ее, в ней много интересного. От Bengt'a давно ничего не получала. ${ }^{654}$ Привет ему. Вам тоже, и благодарность за Ваше милое письмо.

НБерберова

651 See my introduction.

652 See note 270 to Berberova's letter of 1 September 1959.

653 Železnaja ženščina (about Maria Budberg) was published in New York in 1981.

654 Stockholm Slavist Bengt Jangfeldt (b. 1948) also corresponded with Berberova. 
Дорогой Магнус Юнггрен:

пять дней тому назад получила Вашу книгу и сегодня почитала ее. ${ }^{655}$ Прежде чем писать о ней, хочу Вас спросить: не собираетесь ли Вы в США? И если Вы не собираетесь, то не могли бы мы увидеться в Европе, куда я вероятно поеду в этом году. Я чувствую, что мне не только было бы чрезвычайно пприятно Вас увидеть и говорить с Вами, но и что у меня есть потребность встретиться с Вами и кое-что еще Вам рассказать (illegible, M.L.) же, не как просто «слависту« и «беловеду«, но как одному из лучших в наше время специалистов и тонких знатоков Бориса Николаевича. ${ }^{656}$

Я читала Вашу книгу с огромным интересом, и у меня вовсе нет возражений на нее; я поражаюсь Вашим огромным знанием его писаний и его самого. Я знала его хорошо. В моей автобиографии написала о нем осторожно, не желая выпячивать мое с ним близкое знакомство. Я была никто в те времена; я всегда знала, что я с ним и он со мной сблизились только потому, что я - жена его /в то время ближайшего/ друга, не больше. Но в свете Вашей книги я могу кое-что добавить Вам. Я принадлежу к тем, которые уверены /твердо и непоколебимо/, что Б.Н. Фрейда не читал, и как все без исключения люди, рожденные между 1860 и 1900 г.г., поэты и писатели, воспитанные родителями-русскими интеллигентами, заядлыми викторианцами, был заранее не только настроен против него, но ужасался и затыкал нос, когда произносилось его имя; символисты и те, кто были вокруг них, бежали от одной мысли об «анальных синдромах«, комплексе Эдипа, мысли о собственной зачатии и т.п.

Я еще застала время, когда в просвещенных семействах детей от 3-х лет до 14-ти подмывали /Вы знаете, что это значит по-русски/ каждый вечер ледяной водой, чтобы ночью им не снились запретные сны, и этим у девочек отбивали всякий секс, делали калеками.

Вспоминаю отвращение на лице 3.Н. Гиппиус, обожавшей Вейнингера $^{657}$ /которого «обожала« и я, прочитав в 14 лет, и поняв, что он на всю жизнь меня мне самой объяснил/, с любопытством прочитавшей

655 The Dream of Rebirth. A Study of Andrej Belyj's Novel Peterburg (Stockholm 1982).

656 Boris Nikolaevič Bugaev - Belyj's real name.

657 Otto Weininger (1880-1903), author of the famous Geschlecht und Charakter (1903), which pioneered theories about human bisexuality. 
Крафта-Эбинга ${ }^{658}$ и слегка испугавшейся книг Хавелока Эллиса, при имени Фрейда. Ходасевич узнал о нем поздно, в конце 20х г.г., когда я его читала. Он старался у него не учиться, боясь, что его подвергнут остракизму и он не сможет нигде печатать, оказавшись под бойкотом. O конфликте между папочкой и Боренькой он всегда знал, и очень близко к нему подходил. А когда появился Коробкин, ${ }^{659}$ то конечно это на Ход. произвело ошеломляющее впечатление. ${ }^{660}$ Но не буду вдаваться в детали. Перейду к самой книге:

Знаете ли Вы, что в Библиотеке Конгресса в Вашингтоне лежит какаято часть архива Метнера? ${ }^{661}$ Код ее: ДС $24 / 41 /$. Я не знаю, в чем она состоит. Возможно, это пустяки. Но я там буду целый месяц работать /пишу новую книгу/ и могла бы заглянуть в нее. Весь февраль я буду в Калифорнии работать в Архиве Хувера, вернусь на 4 дня домой, и с 1 марта по 31-ое буду в Вашингтоне. Если Вы хотите, чтобы я посмотрела, что там есть, то напишите мне в Принстон так, чтобы получила письмо между 15 и 28 февраля.

Я не знала Юрия Каннабиха, ${ }^{662}$ но в моем «Курсиве« о нем есть 2-3 строки, стр. 110, строка снизу 10-14. Его маленькие рассказы были в «Русской Мысли«, и я оценила их /мне было 14-15 лет/. Его в то время мало кто знал.

Про операцию заднего прохода Борис Ник. рассказывал с подробностями Валентине Ходасевич /племяннице В. Х./, только что с ним познакомившись, за обедом. После чего она отказалась с ним обедать и проводить время. ${ }^{663}$

Все это мелочи, а серьезное я отложу до нашей встречи. Есть у меня и вопросы, но они тоже могут подождать. Один - но посторонний вопрос - для меня важен: почему по-Вашему до сегодняшнего дня

658 Richard von Krafft-Ebing (1840-1902), Austrian neuropathologist, one of the most prominent sex researchers of his time, author of Psychopathia sexualis (1886) which deals with various deviations.

659 The father in Belyj's Moscow novels (Moskovskij čudak and Moskva pod udarom).

660 See Chodasevič's article "Ableuchovy-Letaevy-Korobkiny," originally published in Sovremennye Zapiski 31 (1927).

661 Ėmilii Metner (1867-1936). I was working at this time on my monograph on Metner The Russian Mephisto. A Study of the Life and Work of Emilii Medtner (Stockholm 1994; in Russian translation, Russkij Mefistofel'. Žizn'i tvorčestvo Ėmilija Metnera, St. Petersburg 2001). Berberova's archival discovery was invaluable to me.

662 Jurij Kannabich (1872-1939), pioneer of psychoanalysis in Moscow, subsequently a prominent Soviet psychiatrist, author of Istorija psichiatrii, Leningrad 1928. In 1914 he published several short stories, Sonatiny, in Russkaja mysl'(2).

663 Valentina Chodasevič (1894-1970), artist. 
не вышел 4-ый вып. Лит. Насл. $92 ?^{664}$ Вы знаете, конечно, что я была цитирована в 3-ем /стр. 816 и 819/, и довольно уважительно. Том 93 уже давно пришел. Что случилось? Меня это беспокоит.

Еще раз мне хочется сказать Вам, как дорога мне Ваша книга и как глубоко уважаю Вас за нее. Ее, конечно, необходимо перевести на русский язык.

НБерберова

664 Publication of Literaturnoe Nasledstvo's extensive materials on Blok was interrupted for quite some time after the appearance of 92:1-3 (1980-1982), evidently due in part to the fact that contributor Konstantin Azadovskij was incarcerated in Kolyma. After his release, his section - Blok's annotated correspondence with Nikolaj Kljuev - was finally included in vol. 92:4 (1987). 
Принстон, 7 марта 1985

Дорогой профессор Юнггрен!

Давно ничего не слыхала о Вас. В мае, между 22-м и первыми днями июня я буду в Париже. Мне было бы очень приятно встретиться с Вами. Не будете ли Вы во Франции в это время?

Черкните мне два слова в Принстон, я вылечу 26 апреля в Италию, где хочу отдохнуть в тихом месте, после двух лет работы над книгой о русских масонах XX века, которую только что кончила - 1906-1970.

Не знаете ли Вы, когда выйдет, и выйдет ли, 4-ый том Литературного наследства 92? Меня это беспокоит, потому что уже давно вышел $93 .{ }^{665}$

Бываете ли Вы в Ленинграде и кого там видите? Как проходит Ваша и жизнь и работа в университете?

Буду ждать Вашего ответа. Желаю Вам от души всего лучшего и шлю привет.

НБерберова

$\overline{665}$ See note 664 to Berberova's letter to me of 7 January 1984. 
Принстон, 22 апреля 1985

Дорогой профессор Юнггрен!

Я получила Ваше письмо. Вылетаю 26 в Милан и пробуду в Стрезе до 8-го мая. Между 9 и 20 мая адреса у меня не будет. 21-го я приеду в Париж (рю Бонапарт, отель Бонапарт) куда Вы можете позвонить 28 или 29 утром до десяти. И мы тогда назначим свидание.

Я останусь в Париже до 4 июня. У меня очень большое количество дел - переводчики, издатели, друзья и т.д. Два уик-энда я буду занята придется выехать за город. Из Оксфорда, Хельсинки и с юга Франции также приедут люди повидать меня. Но мы найдем время.

Пишу кратко. Много еще дел надо привести в порядок до отъезда. Жму Вашу руку.

НБерберова 
Принстон, 19 сентября 1986

Дорогой Магнус Юнггрен,

я собираюсь в Москву (и Л.) не раньше мая. В августе я прошла через довольно серьезную операцию. Теперь чувствую себя хорошо. Буду благодарна если напишете две строки из Москвы. Точного ничего сказать не могу: «Вопросы литературы« как будто собираются печатать мемуарную часть «Курсива« ${ }^{666}$ «Знамя« - стихи, а «Дружба народов « - книгу о Будберг. ${ }^{67}$ «Державин« Ходасевича вышел месяц тому назад, тираж - 100.000 - с примечаниями и предисловием, - это Вы знаете! Но Вы возможно не слыхали, что он разошелся в три дня. ${ }^{668}$ Крепко жму Вашу руку.

НБерберова

666 The excerpt from Kursiv moj was published in Voprosy Literatury 11 (1989).

667 Železnaja ženščina appeared in Družba Narodov in 1989.

668 Chodasevič's Deržavin was published in Moscow in 1988. 
Принстон, 1 августа 1988

Дорогой Магнус Юнггрен,

я была тронута посылкой Вами мне книги Ходасевича. Я сегодня же пишу Андрею Зорину. ${ }^{669}$ Вы не дали мне Ваш стокгольмский адрес, и я надеюсь, что Бенгт Янгфельдт перешлёт Вам это письмо. ${ }^{670}$

Я тоже хотела бы с Вами наконец увидеться. У меня идёт довольно интенсивная переписка с журналами Л. и М. И телефон тоже работает. ${ }^{671}$ Я собираюсь быть в Европе в ноябре (во Франции, в Италии и Германии). Может быть мы где-нибудь встретимся с Вами -

На перекрестке двух дорог.

Где время, ветер и песок. ${ }^{672}$

Спасибо еще раз за Ваше внимание ко мне.

НБерберова

669 During a visit to Stockholm, publisher Andrej Zorin had asked me to pass on Chodasevič's Deržavin to Berberova.

670 See note 654 to Berberova's letter of 4 January 1982.

671 This was during glasnost, when all barriers were falling. Berberova's physical return to Russia was only a question of months.

672 Two lines from Chodasevič's poem "Pamjatnik," written in 1928, published in 1939. 